\title{
Fifty Years of Nature Protection in Medimurje County
}

\author{
Sandra Golubić \\ Department of Physical Planning, Construction and Environmental Protection, Environmental and Nature Protection Section, Croatia
}

Copyright $\mathrm{C} 2016$ by authors, all rights reserved. Authors agree that this article remains permanently open access under the terms of the Creative Commons Attribution License 4.0 International License

\begin{abstract}
The plane tree in Nedelišće is the first piece of nature to have been protected in Međimurje, proclaimed to be protected in February, 1963. The foundations for the first official environmental protection were laid by the 1960 Environmental Protection Act. This proclamation has been part of general trends of proclaiming protected areas in Croatia in the past fifty years. The timing and the way of proclaiming protected areas in Međimurje County followed the pattern of proclaiming protected areas in other parts of The Republic of Croatia. The early period of the history of proclaiming protected areas was characterized by a large number of small protected areas. This trend changed over time towards proclaiming a smaller number of larger protected areas. In the same way, Međimurje County proclaimed the area by the Mura River protected in 2001, and ten years later, The Government of the Republic of Croatia proclaimed the areas by the Mura and the Drava Rivers a regional park Mura-Drava. The population density of the county, constant aspirations for economic growth, and a global trend of diminishing biological and landscape diversity require the application of the concept of protection that will take into consideration the singularities and differences within each area.
\end{abstract}

Keywords Protected Areas, Biological and Landscape Diversity

\section{Introduction}

In February 1963, the first natural object between the Mura and the Drava rivers was protected - it was a plane tree in the village of Nedelišće, which officially marked the beginning of evaluation of natural heritage in Međimurje. The first formal nature protection in Međimurje was proceeded by certain activities and agreement between Zagreb and Čakovec [9]. The documents related to nature protection dating back to the time of the protection of the first natural object in Međimurje regularly mention commissioners. At regional level, that is, at the level of municipalities, nature protection rested on the work of commissioners because there were no specialized nature protection institutions at that level [9]. The foundations for the first formal nature protection in Međimurje were laid by the 1960 Nature Protection Act. The first proclamation of protection in Međimurje, as well as all the other proclamations which followed, are not isolated "cases" but part of a pattern and general trends of proclaiming protected areas in Croatia in the past fifty years [10].

Međimurje County is in the northernmost part of the Republic of Croatia. Due to its location in the tri-border area of Slovenia, Hungary and Croatia, its position has a distinctively border character (Figure 1.). The area of Međimurje is bordered by the rivers Mura and Drava in the north and south, and they give it its natural and geographical features. Međimurje is located at the contact of two large morphological units of this part of Europe: the Pannonian Plain and the Eastern Alps. According to the natural-geographic features, there are two distinct basic microregional units: the hilly Upper and the plain Lower Međimurje. In terms of relief, a more pronounced (in relation to the surrounding lowland area) wider contact transition zone between the two microregional units, the so-called Pleistocene Plain, is similar to the Lower Međimurje and it is considered to be its integral part. 


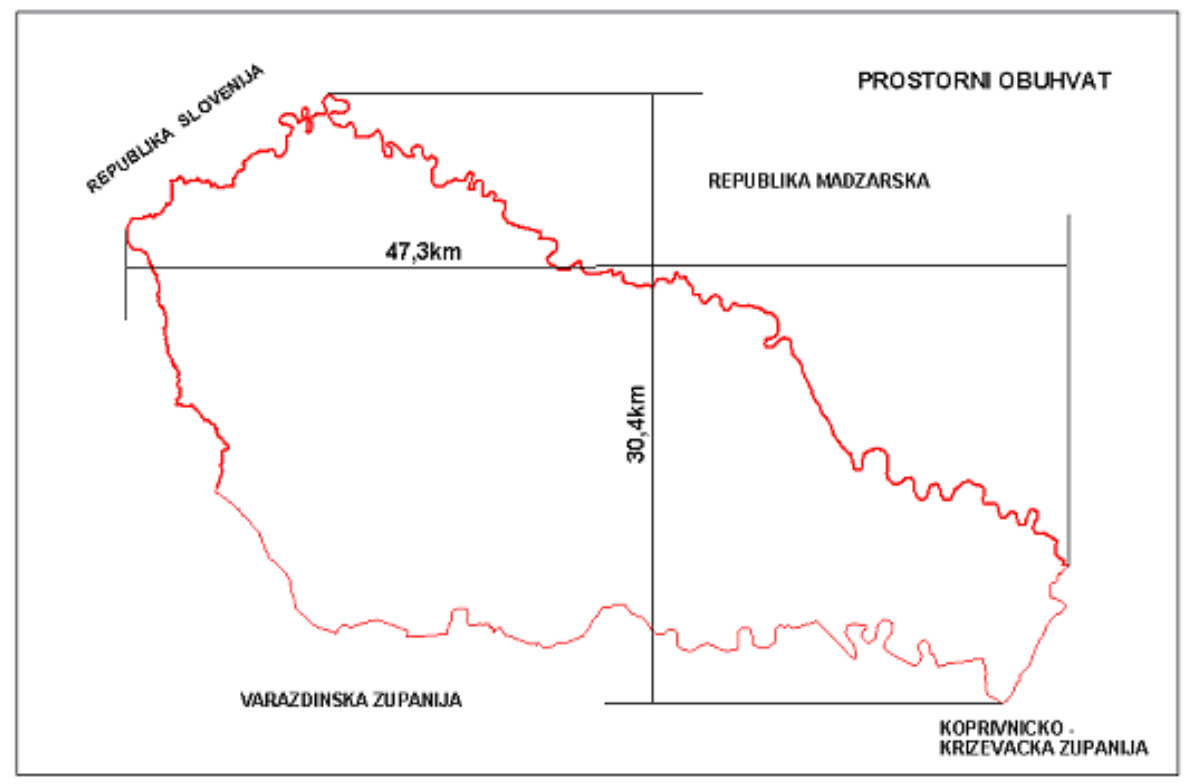

Source: Department of Physical Planning of Međimurje County

Figure 1. Spatial coverage of Međimurje County

Table 1. Međimurje County in the Republic of Croatia

\begin{tabular}{|c|c|c|c|}
\hline & $\begin{array}{c}\text { The } \\
\text { Republic of } \\
\text { Croatia }\end{array}$ & $\begin{array}{c}\text { Medimurje } \\
\text { County }\end{array}$ & $\begin{array}{c}\text { \% in the } \\
\text { Republic of } \\
\text { Croatia }\end{array}$ \\
\hline Area $\left(\mathrm{km}^{2}\right)$ & 56,594 & 729.58 & 1.3 \\
\hline The number of cities & 127 & 3 & 2.4 \\
\hline $\begin{array}{c}\text { The number of } \\
\text { municipalities }\end{array}$ & 429 & 22 & 5.1 \\
\hline $\begin{array}{c}\text { The number of } \\
\text { settlements }\end{array}$ & 6,755 & 131 & 1.9 \\
\hline $\begin{array}{c}\text { Population }(2011 \\
\text { census) }\end{array}$ & $4,284,889$ & 113,804 & 2.7 \\
\hline Inhabitants per $\mathrm{km}^{2}$ & 75.51 & 156.11 & \\
\hline $\begin{array}{c}\text { The number of } \\
\text { households }\end{array}$ & & 35,151 & \\
\hline
\end{tabular}

Source: Međimurje County by Numbers in 2012 (www.udu-mz.hr)

According to the landscape regionalization of Croatia (Physical Planning Strategy of the Republic of Croatia) Međimurje belongs to the landscape of the northwestern Croatia, and according to the visual regionalization (division according to visual experience) Međimurje belongs to the Mura river valley unit. According to its typological characteristics Međimurje landscape (Spatial plan of Međimurje County, 2001) can be classified into several units: the urbanized landscape, the cultivated landscape of the Lower Međimurje, the cultivated landscape of the Upper Međimurje, the predominantly natural landscape of the Mura river and the predominantly natural landscape of the Drava river (a very small portion that refers to the old course of the Drava river).

The urbanized landscape constitutes the middle, most densely populated part of Međimurje, which also belongs to the most densely populated parts of Croatia. The most part of the cultivated landscape of Međimurje is made up of agricultural (agrarian) landscape, and only a smaller part is made up of forests and groves. The landscape has been formed by the traditional agricultural production and by the dense population which is manifested in land fragmentation. The landscape is characterized by a mosaic of plough-fields, meadows, groves, field hedges, and the visual experience of settlements is dominated by a mass of green spaces with a church steeple as a dominant landmark in the plain area. The main feature of the cultivated landscape of the Upper Međimurje is a large share of forests whereas vineyards and orchards prevail in agricultural areas. This is a landscape of great aesthetic value with pronounced open views of the hilly areas. The predominantly natural landscape of the Mura river is a landscape dominated by the natural dynamics of the river, flooded forests and meadows. A distinctively high level of natural values is found within levees which protect the settlements from flooding. Anthropogenic effects are very small. The predominantly natural landscape of the Drava River refers to the area of the old course of the Drava and the remnants of forests remaining after the construction of hydropower facilities. It is a landscape with backwaters and meanders, particularly the area between the end of the drainage canal and the mouth of the Mura.

The area covered by this survey is Međimurje County. Međimurje County is divided into 25 territorial units: 3 cities and 22 municipalities. The paper describes and presents protected segments of nature in the county between 1963 and 2013 as well as the purpose of their protection. It defines the terms of protected areas and shows the legal framework, as well as the management of the protected areas. The paper also describes the area of biosphere reserve, makes recommendations and gives guidelines for measures concerning the preservation of protected areas and the overall nature in the county.

According to the Nature Protection Act, nature is the overall biodiversity, landscape diversity and geodiversity. 
Particularly valuable natural areas are protected under the Environmental Protection Act. Protected areas are reservoirs of biodiversity which form the backbone of the overall protection, and the key nodes of the ecological network.

\section{Protected areas in Međimurje County}

Table 2. Protected areas in Međimurje County

\begin{tabular}{|c|c|}
\hline Protected Area categories & Name \\
\hline Regional Park & Mura - Drava \\
\hline Significant Landscape & Mura \\
\hline Nature monument & The English oak tree (Quercus robur) \\
\hline Nature monument & $\begin{array}{c}\text { Bedekovićeve grabe in the } \\
\text { municipality of Sv. Juraj na Bregu }\end{array}$ \\
\hline Park architecture monument & Zrinski Park in Čakovec \\
\hline Park architecture monument & $\begin{array}{c}\text { The plane tree (Platanus orientalis) in } \\
\text { Nedelišce }\end{array}$ \\
\hline Park architecture monument & $\begin{array}{c}\text { The ginkgo tree (Ginkgo biloba) in } \\
\text { Donja Dubrava }\end{array}$ \\
\hline Park architecture monument & $\begin{array}{c}\text { The two plane trees (Platanus } \\
\text { orientalis) in Sveti Urban }\end{array}$ \\
\hline Park architecture monument & $\begin{array}{c}\text { The tulip tree (Liriodendron tulipifera) } \\
\text { in Vučetinec }\end{array}$ \\
\hline Park architecture monument & $\begin{array}{c}\text { The two wisteria trees } \text { (Wisteria } \\
\text { sinensis) in Čakovec }\end{array}$ \\
\hline Park architecture monument & $\begin{array}{c}\text { The magnolia tree (Magnolia } \\
\text { lilioflora) in Pribislavec }\end{array}$ \\
\hline
\end{tabular}

Basic Guidelines for the Protection of Nature in Croatia are incorporated in the Croatian Constitution and are related to the fundamental rights and freedoms of man and citizen. The basic law regulating the system of protection and conservation of nature and its parts, and other issues in this regards, is the Nature Protection Act (the Act currently in force is the one enacted in 2013). The other basic document of environmental protection is the Strategy and Action Plan for the Protection of Biological and Landscape Diversity of the Republic of Croatia.

Mura-Drava Regional Park, with the surface of 17,007.11 ha $-23.29 \%$ of the county area according to the Protected Areas Register (Figure 2.). According to its values with regard to biodiversity, landscape, cultural and traditional heritage of the area along the Mura and the Drava, it represents an exceptional value at the regional, national and European levels. A special significance of this area is provided by wetland habitats that are rare at the European level [4]. They can still be seen along the two rivers: flooded forests, wet grasslands, oxbow lakes, dried-out river beds, meanders, sandbanks, and steep collapsed banks (Figure 3., Figure 4.). This protected area extends through five counties (Međimurje, Varaždin, Koprivnica-Križevci, Virovitica-Podravina, and Osijek-Baranja) and covers a total of $87,680.52$ hectares. The purpose of protection is to preserve the natural habitat types of all the species that live in them, threatened at the national and European levels, preserving the exceptional landscape value, geological, cultural and traditional heritage. It was declared protected by the Croatian Government in 2011 [4].

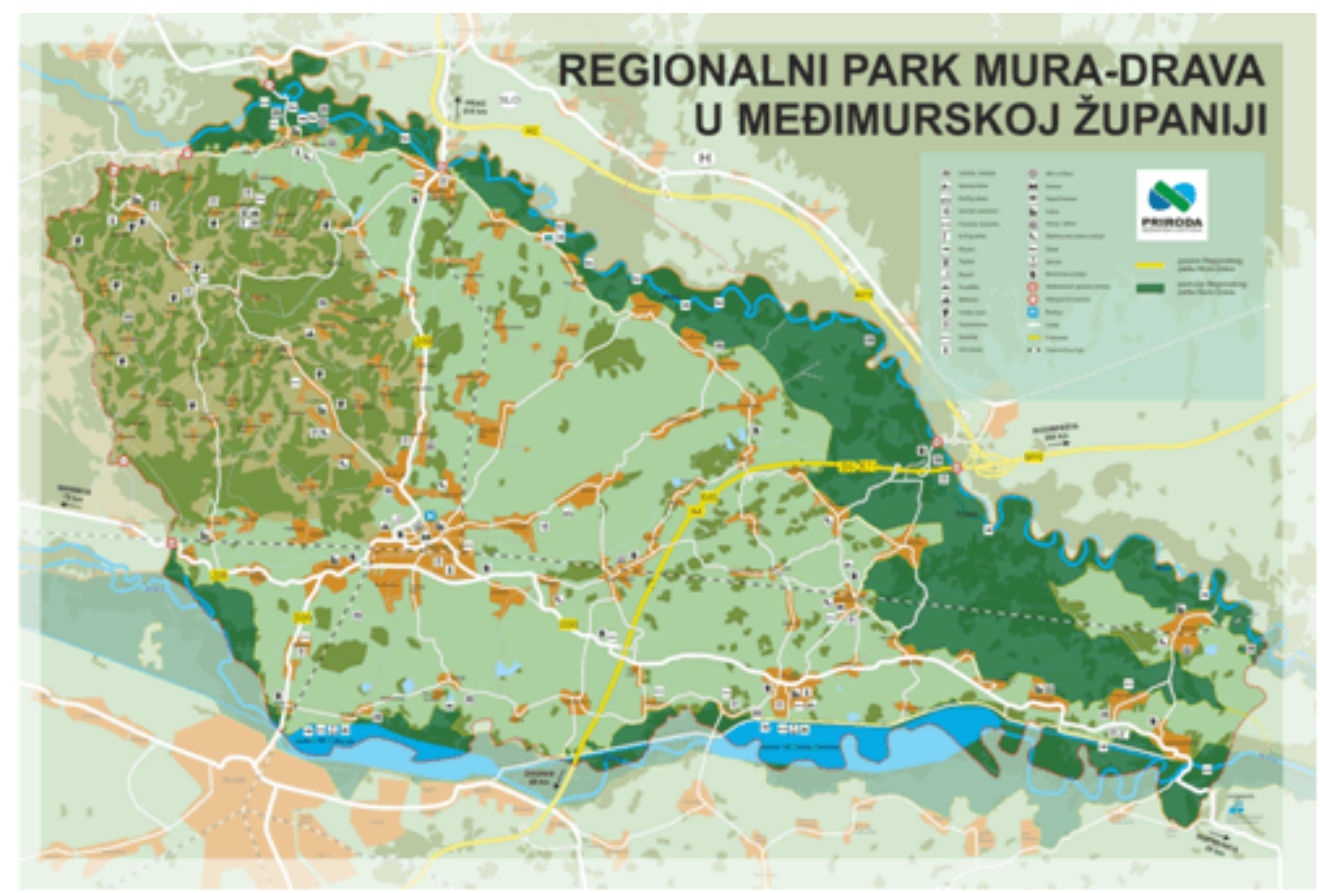

Source: Nature of Međimurje - Public institution for nature protection

Figure 2. Mura-Drava Regional Park in Međimurje 


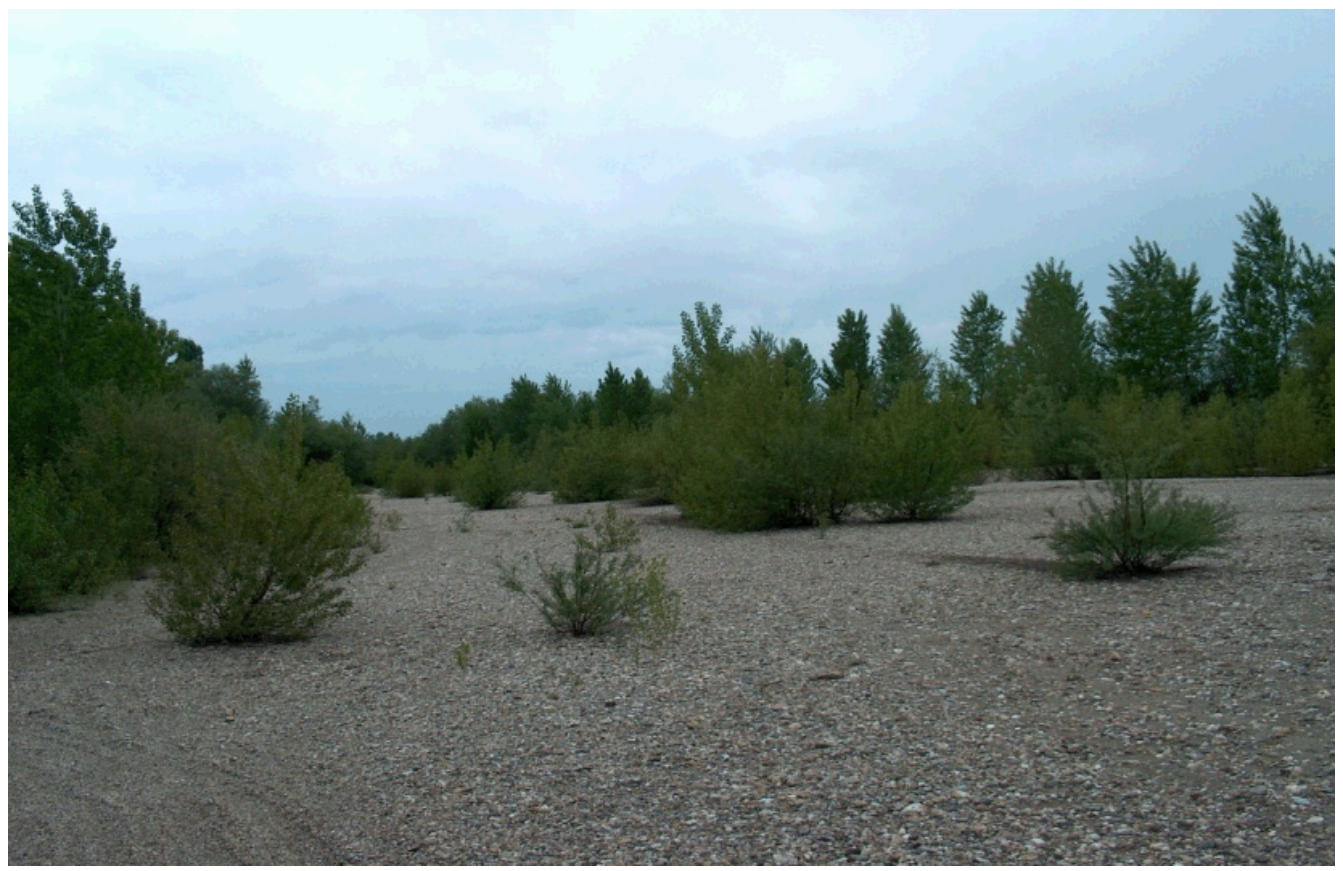

Source: archive author

Figure 3. The area by the Drava River

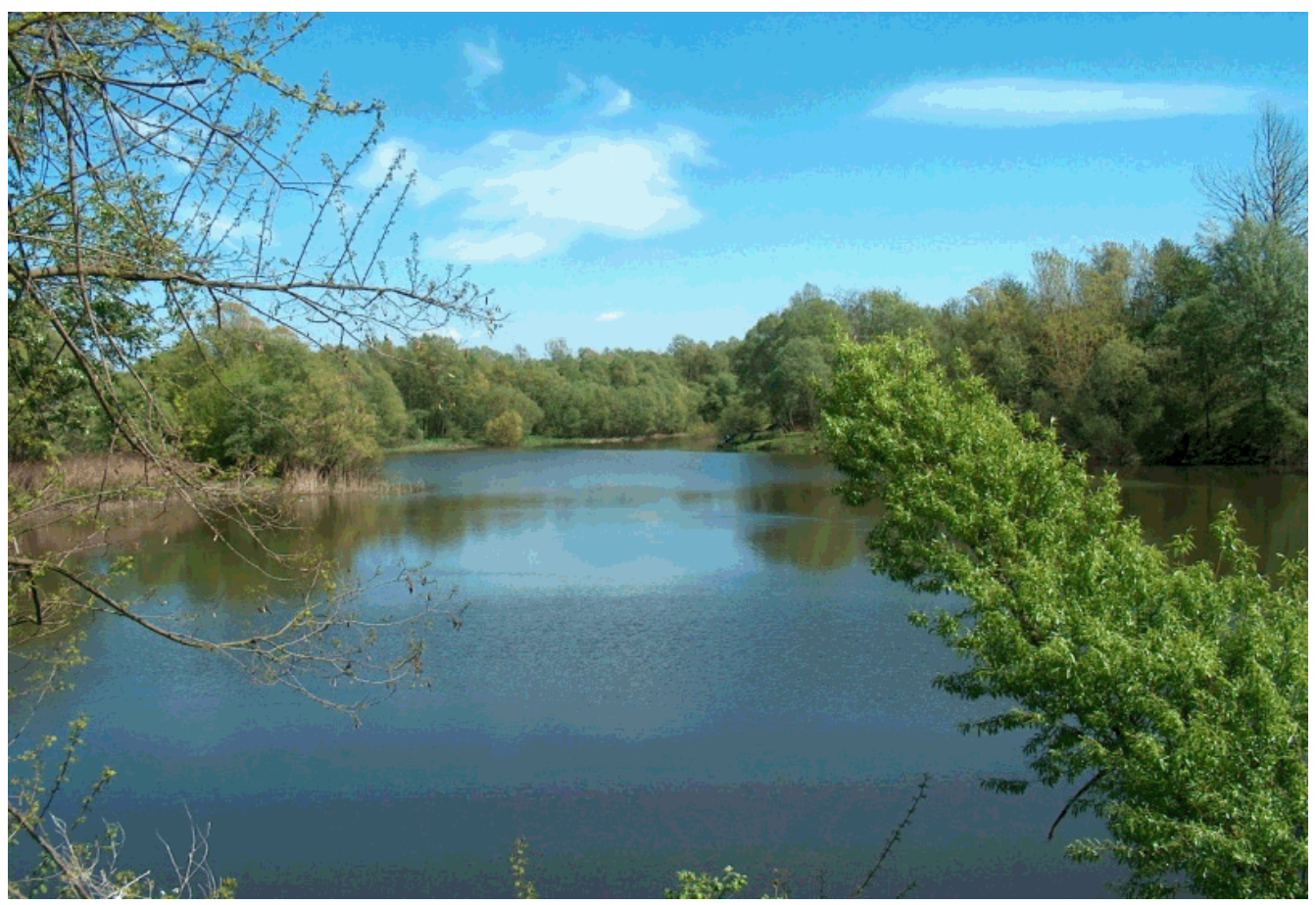

Source: archive author

Figure 4. The old course of the Drava River

The Significant Landscape Mura spans an area of 14,469,4 ha (Figure 5.). The significant landscape of the Mura river due to its natural and cultural values (river dynamics, fluvial wetland sites, flooded forests and meadows, field hedges, agricultural landscapes, dams, settlements) with a wealth of plant and animal species and a high degree of visual harmony is protected in order to preserve local particularities and identity of the whole area of Međimurje (Figure 5., Figure 7.). It was declared protected in 2001 [2]. 


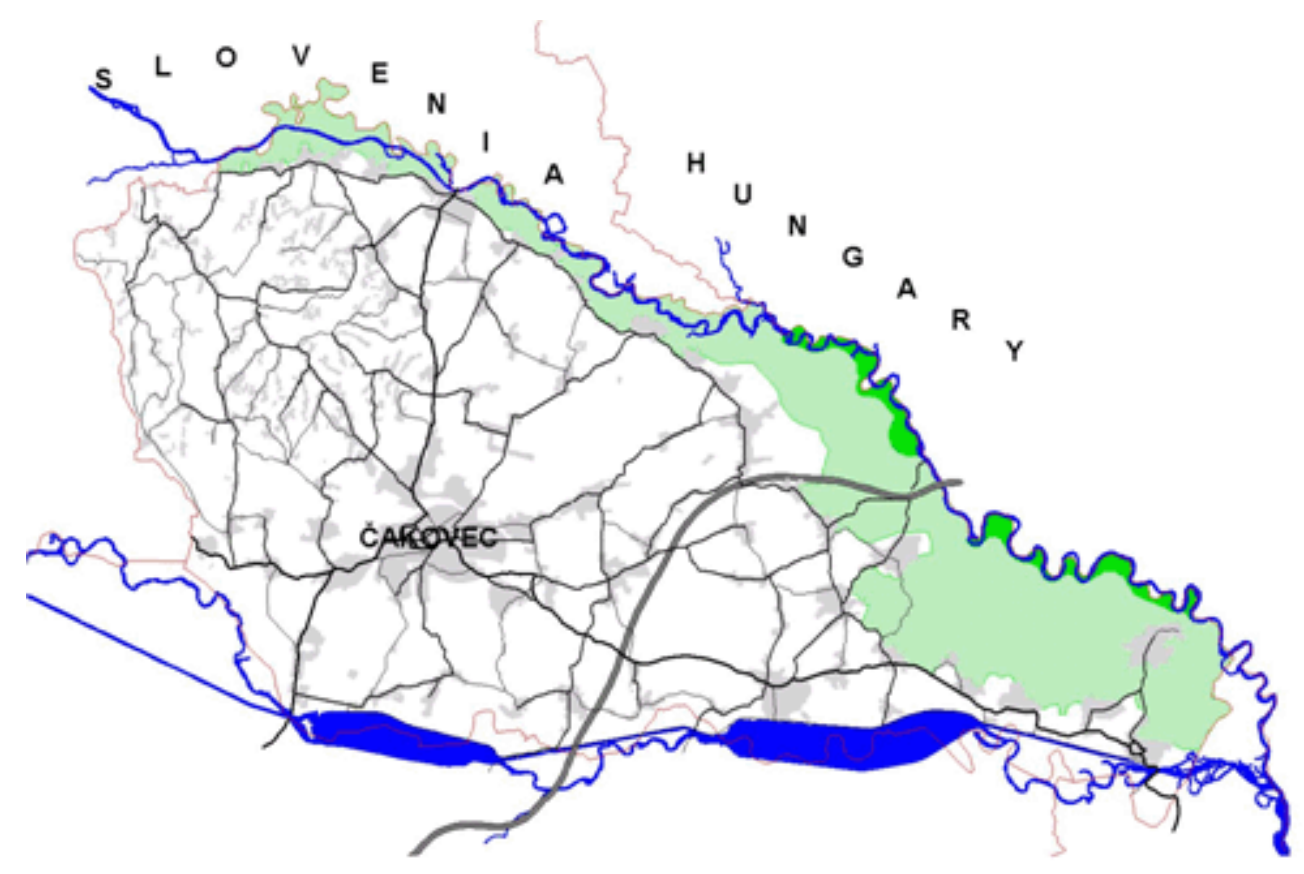

Source: Department of Physical Planning of Međimurje County

Figure 5. The Significant Landscape Mura



Source: archive author

Figure 6. The ferry on the Mura 




Source: archive author

Figure 7. A wooden bridge over a backwater in the Significant Landscape Mura

The English oak tree nature monument (Quercus robur) in Donji Vidovec [2].

It is a protected representative specimen, one of the oldest and most beautiful oak trees in Međimurje, and a rare example of indigenous flora of Međimurje, protected in 1995. (Figure 8)

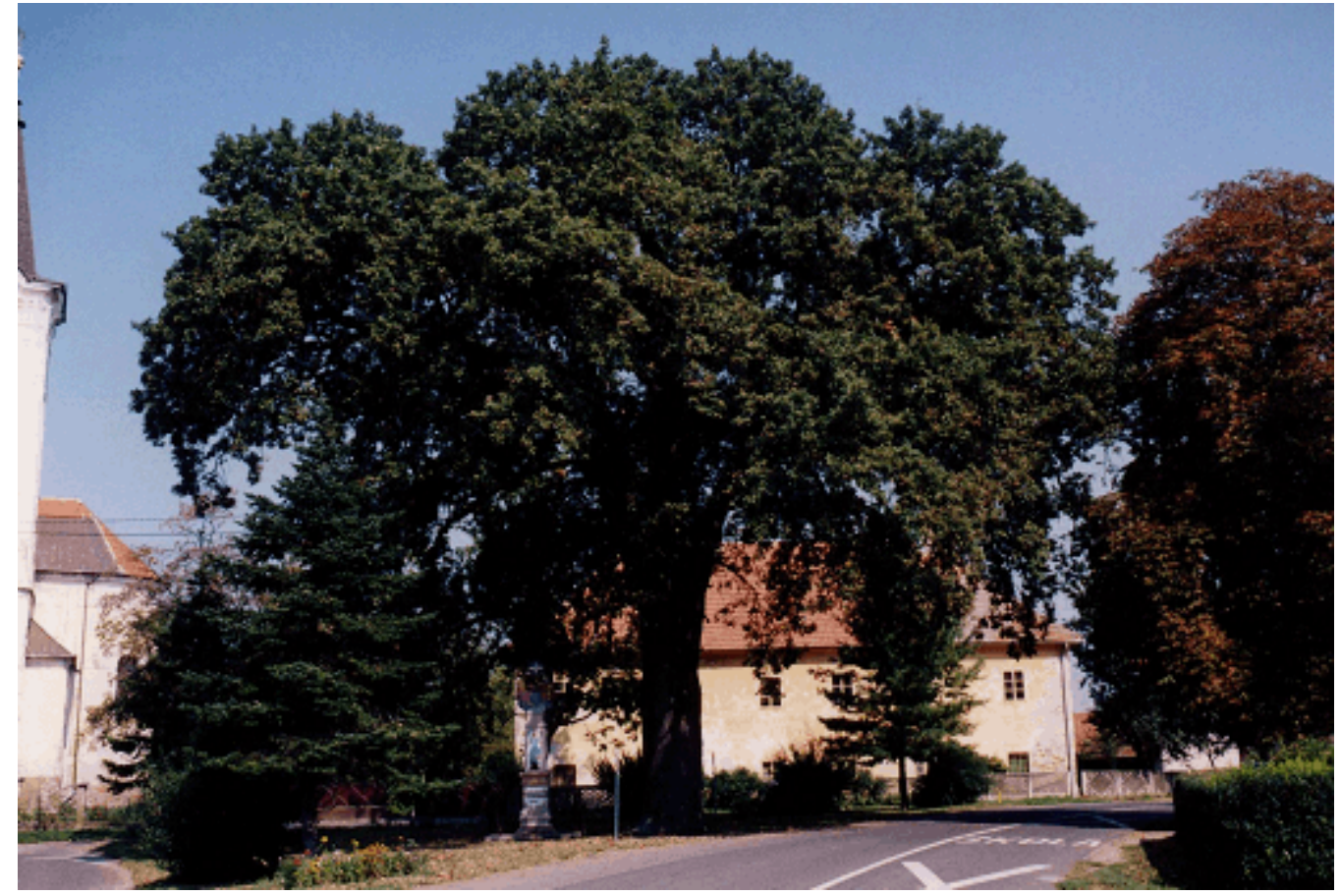

Source: archive author

Figure 8. The English oak tree in Donji Vidovec

Bedekovićeve grabe nature monument spans an area of 13,127 ha in the municipality of Sv. Juraj na Bregu. Bedekovićeve grabe site is the habitat of endangered species of butterflies, the scarce large blue (Phengaris teleius). In the area of Bedekovićeve grabe, during research in the years of 2008, 2009 and 2010 M. Šašić from Croatian Natural History
Museum recorded a total of 63 species of diurnal butterflies which is $30 \%$ of the Croatian diurnal butterfly fauna. The scarce large blue and the dusky large blue ( $P$. nausithous) belong to the most endangered European diurnal butterfly species. Protection of grassland sites important for the survival of diurnal butterflies of the genus Phengaris is one 
of the priority action plans outlined in the National Strategy and Action Plan for the Protection of Biological and Landscape Diversity of Croatia. The site was protected in 2002 [2].

Park architecture monument Zrinski Park (according to the Protected Areas Register, the Park spans an area of 13.3 hectares) in Čakovec. Protected due to its landscape diversity, it stretches around the fortress built in the $16^{\text {th }}$ century by Viceroy Nikola Zrinski. It was protected as a park architecture monument in 1975 for its cultural, historical, horticultural and aesthetic value [2].

The plane tree (Platanus orientalis) park architecture monument in Nedelišće. Protected due to landscape diversity, given the age, size, botanical and aesthetic values, it is a unique specimen in Međimurje. It was protected in 1963. (Figure 9.) [2].

The ginkgo tree (Ginkgo biloba) park architecture monument in Donja Dubrava. Protected due to landscape diversity, it represents a unique specimen of alien flora in the Lower Međimurje and was protected in 1995 [2].

The two plane trees (Platanus orientalis) park architecture monument in Sveti Urban. Protected due to landscape diversity, the plane trees are located within the cultural landscape of the Upper Međimurje, on a farm which cherishes the tradition of viticulture and enology. The trees were protected in 1995 [2].

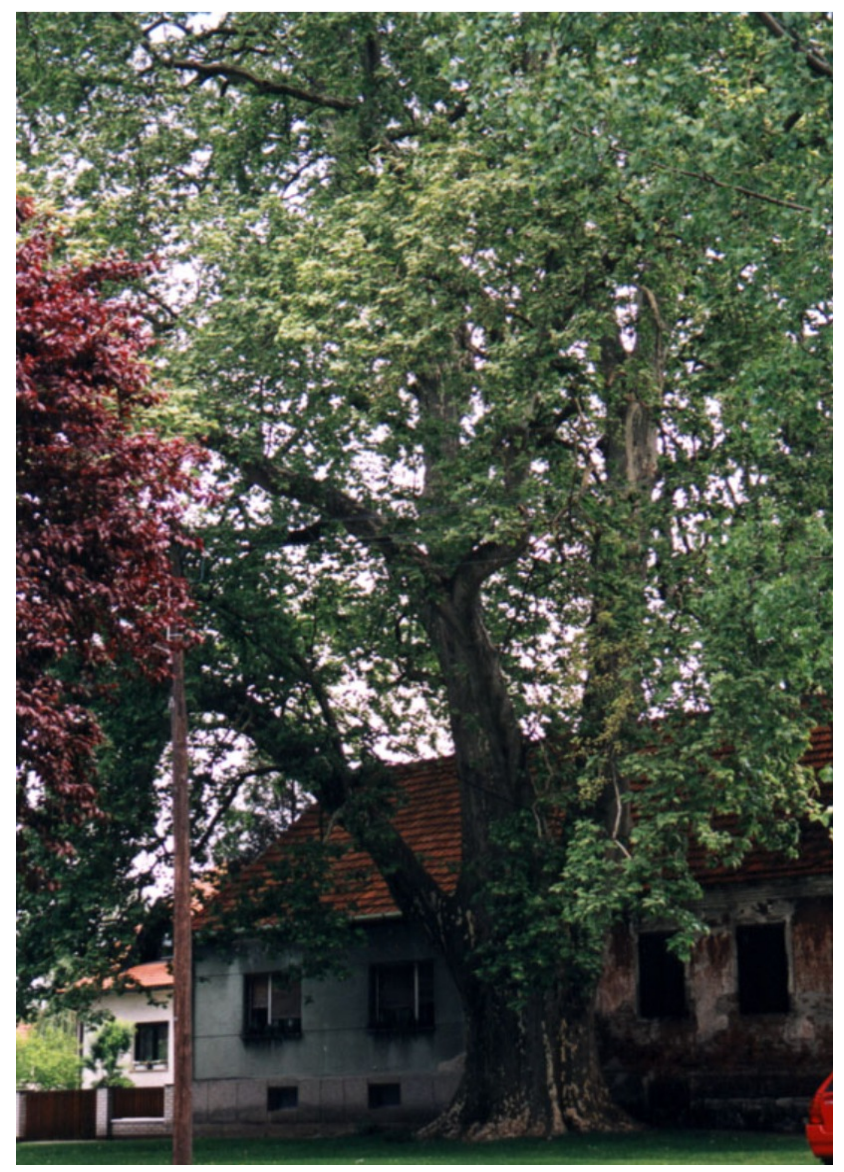

Source: archive author

Figure 9. The plane tree in Nedelišće
The tulip tree (Liriodendron tulipifera) park architecture monument in Vučetinec. Protected due to landscape diversity, a singular specimen of alien flora in the Upper Međimurje; it was protected in 1995 [2].

The two wisteria trees (Wisteria sinensis) park architecture monument in Čakovec, protected in 1995, and the magnolia tree (Magnolia lilioflora) park architecture monument in Pribislavec. Protected due to landscape diversity, the magnolia tree is a decoration of the school housed in the Palace of Count Feštetić in Pribislavec; it was protected in 2001 [2].

Mura-Drava Regional Park and the Significant Landscape Mura are also the areas of the Croatian National Ecological Network. All of the Croatian National Ecological Network can be found at the link: www.bioportal.hr and www.dzzp.hr.

A regional park, a nature monument, a significant landscape and a park architecture monument are protected areas of local importance. Pursuant to the Environmental Protection Act these protected areas in a county are defined as follows:

A regional park - a vast natural or partly cultivated area of land and/or sea of high biodiversity and/or geodiversity with valuable ecological features and landscape values characteristic of the area where it is located.

A significant landscape - a natural or cultivated area of great landscape value and biodiversity and/or geodiversity, or a landscape of preserved unique features characteristic of a particular area.

A nature monument - an individual unmodified segment of nature that has an ecological, scientific, aesthetic or educational value.

A park architecture monument - an artificially designed space (public garden, botanical garden, arboretum, city park) which has an aesthetic, stylistic, artistic, cultural, historical and educational value.

\section{Biosphere Reserve Mura-Drava-Danube}

The Croatian-Hungarian cross-border Biosphere Reserve Mura-Drava-Danube was proclaimed at the $24^{\text {th }}$ session of the International Coordinating Council of the Programme on Man and the Biosphere held from $9^{\text {th }}$ to $13^{\text {th }}$ July 2012 at UNESCO headquarters in Paris [3]. This is the second Croatian biosphere reserve, after the Velebit Mountain which became part of the worldwide network back in 1977. The reserve area in Croatia is $395,860.7$ ha and extends through six northern Croatian counties (Figure 10.). It is marked by great wealth and diversity of aquatic and wetland habitats (sandbanks, oxbow lakes, steep banks, flooded forests, etc.), plant and animal species, especially birds and fish. According to the National Habitat Classification, in the area of biosphere reserve there are 77 habitat types 35 of which are threatened at the European level and are protected by the Habitats Directive [3]. 


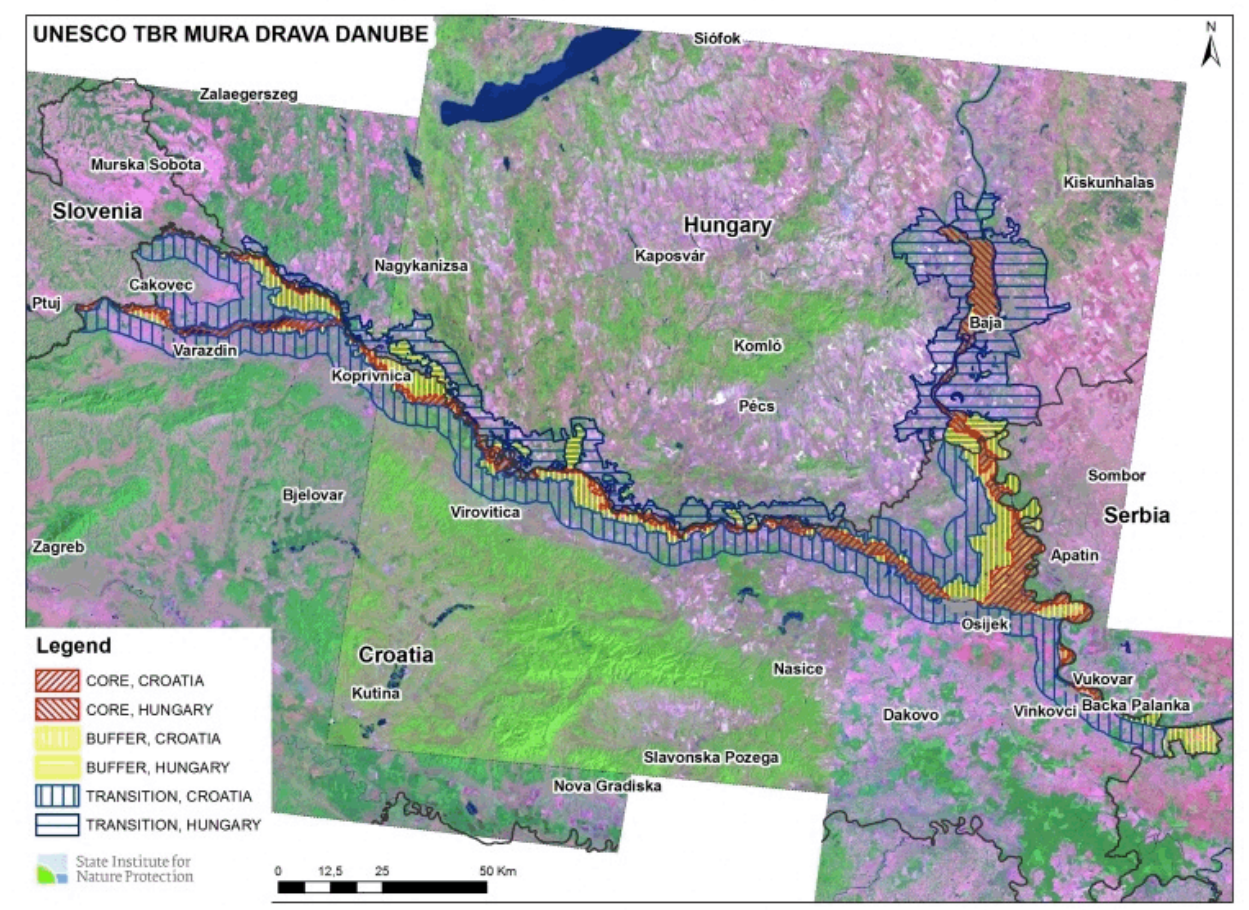

Source: State Institute for Nature Protection

Figure 10. The area of Biosphere Reserve Mura-Drava-Dunav

By accessing the UNESCO World Network of Biosphere Reserves the outstanding natural value of this area at the global and European levels was recognized. Each biosphere reserve should perform three functions that complement each other: the protective function, development function and logistics function. Biosphere reserves are internationally recognized form of protection promoting the harmonious coexistence of man and nature and finding solutions for the harmonization of the preservation of biodiversity and socio-economic development [3].

\section{Protected Area Management}

Pursuant to the Nature Protection Act, protected areas are managed by public institutions. A public institution for management of protected natural areas in the county is established by the County Assembly. Under the Act public institutions perform activities of protection, maintenance and promotion of the protected area in order to protect and preserve the authenticity of nature, ensuring an undisturbed course of natural processes and sustainable use of natural resources. They also monitor the implementation of the conditions and nature protection measures in the area they administer. At the suggestion of the expert services of the County, the Medimurje County Assembly adopted the Decision on Establishing the Public Institution for the Management of Protected Natural Values in Međimurje in November 2005. The institution, in accordance with the law, has the Statute adopted by the Governing Council in February 2006, which regulates all the rights of importance for performing its activities and operations. This was followed by the establishment of the institutional bodies provided by the Statute [5]. The Institution started its work in 2007. Today the institution operates under the name of Međimurska priroda (Nature of Međimurje) - Public Institution for Nature Protection. Its seat is in the village of Križovec, Trg međimurske prirode 1, in the district of the city of Mursko Središće [9].

\section{Conservation Measures - Recommendations}

Changes in natural and semi-natural habitats, including the loss, fragmentation and degradation of habitats are the cause of significant adverse effects that may occur due to the expansion of the construction areas, agricultural intensification, and land abandonment. Over-exploitation of resources remains a major concern. In order to reduce these changes, over-exploitation and pressures, the following precautionary measures should be taken [5]:

- not to change the existing habitats, especially marshes and wetlands that are significantly shrinking, implement conservation measures concerning endangered and rare habitat types,

- the projects planned for the area should change as little as possible the natural features of the landscape in order to preserve local particularities. Transformation of agricultural space results in the loss of diversity of cultural landscapes of Međimurje,

- to ensure, if possible, the preservation of the existing natural banks without water management structures and 
river training interventions,

- not to clear the hedges along the paths and boundary lines because they are important habitats for various species,

- not to disturb birds in their nesting period and in critical seasons (in winter),

- to prevent further unplanned construction and construction in the floodplain area,

- to ensure the strengthening of cooperation with cross-border protected areas in order to improve the quality of management,

- to encourage systematic floristic, faunistic, mycology, environmental and geological studies, because their results will significantly contribute to the proper management; to create a plan of protected areas management on the basis of these results by cooperating with all the people and institutions in the area.

\section{Conclusions}

The conclusion is that in the last fifty years the following objects and areas have been protected in Međimurje pursuant to the Nature Protection Act: eight trees in the category of park architecture monument, one tree in the category of nature monument, Zrinski Park in the category of park architecture monument, the area along the Mura and Drava rivers in the categories of significant landscape and regional park, and Bedekovićeve grabe site in the category of nature monument. Altogether, this makes about 31,480 ha of protected areas in Međimurje, or it can be said that $43 \%$ of the total area of Medimurje is protected pursuant to the Environmental Protection Act.

It is important to emphasize that, in accordance with the recommendations for conservation measures for protected areas, apart from administrative protection, professional approach is necessary to carry out the protection, maintenance and promotion activities in Međimurje. In order to preserve the landscape, geological and biological values of protected areas and particularities of Međimurje, management plans for protected areas should be developed.

Protection of nature as a comprehensive social interest in the field of human activity with the aim of a better and more humane life can be made effective only by creating a unique and functional system of protection. In the future it will be necessary to harmonize legislation in the field of nature protection, and harmonize other sectors (water and forest management etc.) with the needs of nature and environmental protection, improve or strengthen inspection and increase the financial capacity of public institutions for management of protected natural values of the counties.

\section{REFERENCES}

[1] SINP GIS Database of Protected Areas

[2] SINP, Zagreb - Nature Protection Information System, (http://www.dzzp.hr/informacijski-sustav-zastite-prirode/baz e-podataka-i-web-karte-170.html)

[3] SINP, Zagreb - Cross-border Biosphere Reserve, (http://www.dzzp.hr/novosti/k/prekogranicni-rezervat-biosfe re-mura- $\%$ E2\%80\%93-drava- $\%$ E2\%80\%93-dunav-1138.htm 1)

[4] SINP 2010: Expert basis for proclamation of the Mura-Drava in Croatia a regional park, Zagreb

[5] Environmental Status Report of Međimurje County, 2014 Department of Physical Planning, Construction and Environmental Protection of Međimurje County, Department of Environmental and Nature Protection, Cakovec, Međimurje County Official Gazette number 13/2014

[6] Janev Hutinec, B., Jovanović, O., Šafarek, Mr. Jankovic, S., 2013: The Frog, Snake, Lizard - Amphibians and Reptiles in Međimurje, Nature of Međimurje - Public Institution for the Protection of Nature, Križovec

[7] Martinić, I., 2010 The Management of Protected Natural Areas - Planning, Development and Sustainability, Zagreb, University of Zagreb, Faculty of Forestry

[8] The Ministry of Environment and Nature Protection, Zagreb the Protected Areas Register

[9] In the Beginning Was a Tree - 50 Years of Nature Conservation in Medimurje 1963-2013, Public Institution for Management of Protected Natural Values in Međimurje, 2013.

[10] Zupan, I., 2012: Patterns of Protected Area Designations in Greece. A master thesis submitted for the degree of Master of Science in Management of Protected Areas at the University of Klagenfurt, Austria 